\title{
Peningkatan Kualitas Tepung Jali (Coix lacryma-jobi L.) melalui Fermentasi Menggunakan Bakteri Amilolitik-Selulolitik dan Bakteri Asam Laktat Terseleksi [Jali (Coix Lacryma-jobi L.) Flour Quality Improvement Through Fermentation Using Selected Amylolytic-Cellulolytic and Lactic Acid Bacteria]
}

\author{
Yati Sudaryati Soeka \& Sulistiani \\ Bidang Mikrobiologi, Pusat Penelitian Biologi- LIPI. Jl. Raya Bogor Km 46, Cibinong 16911. Telp. 021- \\ 8765066, Fax. 021-8765062. E-mail: ceuceu_lipi@yahoo.com
}

Memasukkan: Januari 2021, Diterima: Maret 2021

\begin{abstract}
Adlay (Coix Lacryma-jobi L.), is a kind of grain plants (cereals) from parts of tropical cereals (Poaceae). Adlay contains starch in a high amount, therefore it has the potential to be used as raw material for making flour. The aim of this study is to produce adlay flour by submerged fermentation of amylolytic-cellulolytic bacteria Bacillus amiloliquifaciens $\mathrm{B}_{7}$ and phytic acid hydrolyze lactic acid bacteria Lactobacillus plantarum SU-LS537. The turbidity (OD) $\lambda 600 \mathrm{~nm}$, Total Plate Count (TPC), content water, ash, fat, protein, carbohydrates, dietary fiber, whiteness, gluten, phytic acid, vitamin $\mathrm{E}$, vitamin $\mathrm{B}_{6}$, vitamin $\mathrm{B}_{12}$, calcium, $\mathrm{pH}$, final weight, essential and non-essential amino acids, essential fatty acids and non-essential of submerged fermentation of adlay was determined in this study. The results show that with fermentation there was quite an increase of the nutritional quality compared to without fermentation of the content (ash, protein, and carbohydrates), dietary fiber, calcium, essential amino acids and non-essential, essential fatty acids and nonessential.
\end{abstract}

Keywords: adlay (Coix lacryma-jobi L.), amylolytic-cellulolytic bacteria, lactic acid bacteria.

\section{ABSTRAK}

Jali (Coix lacryma-jobi L.), merupakan sejenis tumbuhan biji-bijian (serealia) tropika dari suku padi-padian (Poaceae). Kandungan pati jali cukup tinggi, sehingga memiliki potensi dijadikan bahan baku pembuatan tepung. Pada penelitian ini dilakukan pembuatan tepung jali secara fermentasi dengan starter dari bakteri amilolitik-selulolitik Bacillus amiloliquifaciens $\mathrm{B}_{7}$ dan bakteri asam laktat yang dapat mendegradasi asam fitat Lactobacillus plantarum SU-LS537. Parameter yang diukur pada jali tanpa fermentasi dan fermentasi adalah kekeruhan (OD) $\lambda 600 \mathrm{~nm}$, Angka Lempeng Total (ALT), kadar air, abu, lemak, protein, karbohidrat, serat pangan, derajat putih, gluten, asam fitat, vitamin $\mathrm{E}$, vitamin $\mathrm{B}_{6}$, vitamin $\mathrm{B}_{12}$, kalsium, $\mathrm{pH}$, berat akhir, asam amino esensial dan non-esensial, dan asam lemak esensial dan non-esensial dari tepung jali. Hasil analisis menunjukkan peningkatan fermentasi jali kualitas nutrisi dibanding tanpa fermentasi pada kadar (abu, protein, karbohidrat), serat pangan, kalsium, asam amino esensial dan non-esensial, asam lemak esensial dan nonesensial.

Kata Kunci : jali (Coix lacryma-jobi L.), bakteri amilolitik-selulolitik, bakteri asam laktat.

\section{PENDAHULUAN}

Pada suatu negara yang menghadapi persoalan kemiskinan maka cenderung akan menghadapi persoalan ketahanan pangan (Darmawan 2015). Kelangkaan sumber pangan menjadi salah satu masalah utama dunia, khususnya di negara berkembang termasuk Indonesia. Hal ini terjadi karena kurangnya akses untuk mendapatkan bahan pangan dan naiknya harga pangan (Sholikhah dkk. 2010). Masalah ketahanan pangan ini dapat diatasi dengan diversifikasi pangan berbasis bahan pangan dasar lokal
(Elizabeth 2011).

Tanaman jali (Coix lacryma-jobi L.) adalah sejenis tumbuhan serealia tropika dari suku padipadian (Poaceae) berasal dari Asia Timur dan Malaya, tetapi sekarang telah tersebar ke berbagai penjuru dunia (Marco \& Wunwisa 2012). Masyarakat lokal di Indonesia biasanya mengolah jali menjadi berbagai makanan seperti nasi, bubur, aneka macam kue (baik basah maupun kering), dan makanan fermentasi seperti tape (Juhaeti 2015).

Jenis jali var. ma-yuen telah lama dibudidayakan di negara-negara oriental sebagai 
sereal sumber pangan dan sebagai tanaman obat tradisional karena kandungan dari fitonutrisi vitamin E dan asam lemaknya (Bhandari et al. 2012). Jenis ini memiliki cangkang yang tipis dan mudah dipecahkan, sehingga mudah untuk mendapatkan biji dalamnya untuk bahan pangan (Nurmala 2003).

Hasil penelitian para ahli di dalam biji jali terkandung kalori, protein, karbohidrat, serat, kalsium, zat besi, dan beberapa vitamin, seperti riboflavin (vitamin $\mathrm{B}_{2}$ ), tiamin (vitamin $\mathrm{B}_{1}$ ) dan niacin (vitamin $\mathrm{B}_{3}$ ). Bahkan proteinnya dua kali lipat dari jumlah yang ada dalam beras. Penelitian obat modern mengungkapkan bahwa biji jali mengandung berbagai sumber zat aktif yang dapat diperoleh baik dari biji maupun dari ekstrak akarnya. Biji jali digunakan untuk mengobati rematik dan neuralgia, anti inflamasi dan agen antelmintik, anti-proliferative (perkembangan) sel kanker, anti kanker dan anti alergi (Hsu et al. 2003; Chang et al. 2003; Manosroi et al. 2015; Mustarichie et al. 2011; $\mathrm{Qu}$ et al. 2014). Menurut Gan et al. (2017) serealia atau biji-bijian yang dapat dimakan apabila difermentasi umumnya produknya mengandung peningkatan komponen bioaktif, seperti beberapa vitamin, $\gamma$-aminobutyric acid (GABA), fenolat alami, dan peptida bioaktif, dibandingkan dengan bahan yang tidak difermentasi, sehingga dapat direkomendasikan untuk dikonsumsi sebagai bagian dari komponen makanan dan dikembangkan menjadi makanan fungsional untuk mencegah penyakit kronis.

Beberapa kajian terkait dengan bakteri asam laktat telah banyak dilakukan kajian sebagai contoh yang dilakukan oleh Afiati dkk. (2015) terkait dengan sel darah domba, Sulistiani (2017) menggunakannya sebagai bahan pengawet ikan, Sulistaini (2020) telah menyeleksi bakteri asam laktat dari nira aren dan Handayani (2018) melakukan fermentasi jali menggunakan bakteri selulolitik dan bakteri asam laktat untuk pembuatan tepung. Pada penelitian ini kami mencoba untuk mengevaluasi sifat fisikokimia dan komposisi gizi dari tepung jali lokal yang tidak dan yang difermentasi oleh bakteri amilolitik-selulolitik Bacillus amyloliquifaciens B7 dan bakteri asam laktat Lactobacillus plantarum SU-LS537 sebagai pendegradasi asam fitat.

\section{BAHAN DAN CARA KERJA}

Bahan untuk pembuatan tepung secara fermentasi adalah jenis jali kuning (Coix lacryma-jobi L.) yang berasal dari Kuningan, Jawa Barat. Bakteri Bacillus amyloliquifaciens $\mathrm{B}_{7}$ yang dipakai pada penelitian ini berasal dari makanan fermentasi (terasi dari Samarinda), bakteri tersebut dapat mendegradasi amilum dan selulosa. Bakteri ditumbuhkan dalam medium Nutrient Agar miring dengan komposisi: beef ekstrak 0,3 g, pepton $0,5 \mathrm{~g}$, bakto agar 2,0 $\mathrm{g}$ dan $100 \mathrm{~mL}$ akuades kemudian diinkubasi selama tiga hari di dalam inkubator pada temperatur $37^{\circ} \mathrm{C}$. Bakteri asam laktat SU-LS537 adalah isolat yang dapat mendegradasi asam fitat berasal dari makanan fermentasi sayur asin dari Solo, Jawa Tengah. Bakteri BAL ini ditumbuhkan dalam medium MRSA (deMann Rogosa Sharpe Agar) yang mengandung asam fitat, diinkubasi secara anaerobik dengan cara dimasukkan petri berisi bakteri BAL ke dalam anaero jar yang telah diberi Anaerocult A diinkubasi selama tiga hari pada temperatur ruang $\left(28-30^{\circ} \mathrm{C}\right)$. Media yang digunakan untuk seleksi enzim selulase adalah media spesifik yang mengandung CMC $1 \%$ dengan komposisi media: $\mathrm{KH}_{2} \mathrm{PO}_{4} \quad 2,0 \%$; $\quad\left(\mathrm{NH}_{4}\right)_{2} \mathrm{SO}_{4} \quad 1,4 \%$; $\mathrm{MgSO}_{4} .7 \mathrm{H}_{2} \mathrm{O}$ 0,3\%; $\mathrm{CaCl}_{2}$ 0,3\%, peptone 2,0\%, agar $5 \%$ dilarutkan dengan akuades dan disterilisasi. Media yang digunakan untuk seleksi enzim $\alpha$-amilase adalah media spesifik YPSs (Yeast Pepton Starch soluble) yang mengandung pati terlarut $2 \%$ dengan komposisi: ekstrak khamir $0,2 \%$, pepton $0,5 \%, \mathrm{KH}_{2} \mathrm{PO}_{4}$ $0,3 \%, \mathrm{MgSO}_{4} .7 \quad \mathrm{H}_{2} \mathrm{O} \quad 0,05 \%, \mathrm{CaCl}_{2} .2 \quad \mathrm{H}_{2} \mathrm{O}$ $0,01 \%$ dan $5 \%$ agar dilarutkan dengan akuades dan disterilisasi. Media yang digunakan untuk seleksi enzim fitase adalah media MRSA yang dimodifikasi mengandung glukosa $0,5 \%$, tanpa $\mathrm{K}_{2} \mathrm{HPO}_{4}$ dan mengandung asam fitat $1 \%$. Penapisan bakteri-bakteri penghasil selulase dengan cara isolat bakteri yang telah tumbuh ditotolkan sebanyak ujung ose di atas media yang mengandung CMC 1\% kemudian diinkubasi selama 3 hari. Untuk mengetahui aktivitas selulase, media dituangi dengan Congo red 0,1\% dibiarkan selama 15-30 menit setelah itu dicuci dengan $\mathrm{NaCl} 0,15 \mathrm{~N}$. Apabila pada media di sekitar koloni menghasilkan zona bening 
menunjukkan bakteri dapat menghasilkan enzim selulase. Dipilih isolat yang mempunyai zona bening terbesar.

Hasil penapisan bakteri penghasil selulase diuji untuk dapat mendegradasi amilum dengan cara isolat bakteri yang telah tumbuh ditotolkan sebanyak ujung ose di atas media YPSs yang mengandung pati $1 \%$ kemudian diinkubasi selama 3 hari di dalam inkubator pada suhu $37^{\circ} \mathrm{C}$. Untuk mengetahui aktivitas amilase, medium dituangi dengan lugol iodine 1\%. Apabila pada media di sekitar koloni menghasilkan zona bening hal itu berarti bakteri dapat menghasilkan enzim amilase.

Penapisan dari tiga bakteri bakteri asam laktat (SU-LS530, SU-LS537 dan SU-LS540) penghasil fitase dengan cara isolat bakteri ditusukan pada media MRSA yang dimodifitasi tanpa fosfat kemudian diinkubasi selama empat hari. Untuk mengetahui aktivitas fitase, media dituangi dengan $\mathrm{CoCl}_{2} 2 \%$. Bila masih belum terlihat zona beningnya ditambahkan $0,5 \%$ ammonium monovanadat. Media MRS modifikasi akan berwarna putih keruh dan koloni yang menghasilkan zona bening merupakan bakteri yang menghasilkan fitase. Isolat dipilih yang mempunyai zona bening terbesar.

Identifikasi secara molekuler isolat bakteri asam laktat SU-LS537 yang dapat menghasilkan enzim fitase dengan sekuensing 16S rDNA di Basic Local Aligment Search Tool (BLAST) ke GenBank NCBI data Library. Analisis filogenetik sekuen 16S rDNA strain SU-LS537 dilakukan menggunakan program Molecular Evolutionary Genetic Analysis (MEGA) versi 5.2 dengan Multiple Sequence Comparison by Log-Expectation (MUSCLE) (Tamura et al. 2011). Konstruksi pohon filogenetik berdasarkan jarak kekerabatan genetik dengan metode neighbor joining (NJ) (Saitou \& Nei 1987). Parameter-parameter yang digunakan yaitu: model substitusi menggunakan Kimura 2-parameter model, gap diperlakukan sebagai 'missing data'. Pemilihan model substitusi didasarkan dari hasil analisis menggunakan Find best DNA/Protein Models (ML) pada program MEGA. Kekuatan pohon filogenetik diuji menggunakan metode bootstrap (Efron 1979) dengan 100 kali ulangan.

Komposisi media untuk starter bakteri amilolitik-selulolitik adalah jali $2 \%$, ekstrak yeast $1 \%$, dan pepton $2 \%$. Sedangkan untuk starter bakteri asam laktat penghasil fitase adalah media MRS yang ditambah $2 \%$ jali. Semua bahan tersebut dilarutkan ke dalam 250 $\mathrm{mL}$ akuades di dalam labu Erlenmeyer $500 \mathrm{~mL}$ kemudian dikocok supaya semua bahan tercampur. Selanjutnya sterilisasi dengan cara ditutup rapat menggunakan sumbat kapas mulut labu menggunakan autoclave pada suhu $121^{\circ} \mathrm{C}$, 1 atmosfir selama 15 menit. Setelah dingin diinokulasi dengan bakteri dan selanjutnya digoyang $\mathrm{di}$ atas shaker inkubator dengan kecepatan $120 \mathrm{rpm}$ suhu $37^{\circ} \mathrm{C}$ selama tiga hari. Setiap hari pengambilan sampel untuk pengukuran $\mathrm{pH}$, kekeruhan Optical Density (OD) dengan spektrofotometer pada $\lambda 600 \mathrm{~nm}$, dan total bakteri dengan beberapa variasi pengenceran.

Analisis total bakteri dilakukan dengan seri pengenceran sampai pada tingkat pengenceran $10^{-7}$ dimulai dari $1 \mathrm{~mL}$ sampel starter yang telah difermentasi dengan isolat $\mathrm{B}_{7}$ dan bakteri asam laktat SU-LS537. Sebanyak $1 \mathrm{ml}$ suspensi sampel dari hasil pengenceran $10^{-5}, 10^{-6}, 10^{-7}$ dimasukan ke dalam cawan petri yang berisi 15 $\mathrm{ml}$ medium Nutrient Agar (NA) lalu cawan petri digoyangkan supaya sampel menyebar merata dan diinkubasi selama 24-72 jam pada temperatur $30^{\circ} \mathrm{C}$. Koloni yang tumbuh diamati dan dihitung jumlahnya untuk memperoleh Total Plate Count (TPC) dilakukan secara duplo. Perhitungan TPC dilakukan dengan rumus sebagai berikut: TPC $($ koloni $/ \mathrm{mL})=$ Jumlah koloni per cawan $\mathrm{x}$ (1/faktor pengenceran) (Salosa 2013) .

Pembuatan tepung jali secara fermentasi yaitu jali yang sudah kering disosoh, dipisahkan antara kulit dengan daging jali lalu dicuci sampai kotorannya hilang, ditiriskan. Tiga wadah dari bahan plastik aman untuk dipakai makanan yang sudah dicuci dengan alkohol dan kering, dimasukkan masing-masing $200 \mathrm{~g}$ jali ke dalam wadah ditambah akuades steril sebanyak $300 \mathrm{~mL}$ dan diinokulasikan dengan :

- Wadah pertama diinokulasi $1 \%$ dengan starter penghasil selulase dan amilase;

- Wadah kedua diinokulasi $2 \%$ dengan starter bakteri asam laktat penghasil asam fitat;

- Wadah ketiga diinokulasi $1 \%$ dengan starter penghasil selulase dan amilase dan diinokulasi $2 \%$ dengan starter bakteri asam laktat penghasil enzim fitase. 
Semua wadah ditutup dengan kain kasa bersih kering setelah disemprot alkohol, diinkubasi pada suhu ruang selama 24 jam. Setelah inkubasi satu hari satu malam jali ditiriskan. Jali dioven dengan suhu $50^{\circ} \mathrm{C}$ selama 24 jam sampai kering. Jali kasar kering diblender sampai halus dan dianalisis yang terdiri dari kadar air, abu, lemak, protein, karbohidrat, serat pangan, derajat putih, gluten, asam fitat, vitamin $\mathrm{E}$, vitamin $\mathrm{B}_{6}$, vitamin $\mathrm{B}_{12}$, kalsium, $\mathrm{pH}$, berat akhir, asam amino esensial dan non-esensial dan asam lemak esensial dan non-esensial. Sebagai pembanding, tepung jali tanpa fermentasi juga dianalisa dengan parameter yang sama.

Identifikasi asam amino dengan Kromatografi Cair Kinerja Tinggi (KCKT) Ultimate 3000. Preparasi sampel enam puluh miligram sampel ditambah $4 \mathrm{ml} \mathrm{HCl} 6 \mathrm{M}$, kemudian dipanaskan selama 24 jam dengan suhu $110^{\circ} \mathrm{C}$. Selanjutnya hasil hidrolisis dinetralkan dengan $\mathrm{NaOH} 6 \mathrm{M}$ hingga $10 \mathrm{ml}$ dan disaring dengan kertas saring Whatman 0,2. Dua puluh lima mikroliter sampel dimasukkan ke dalam tabung uji ditambah larutan OPA (Ortophalaldehid) sebanyak 300 $\mu \mathrm{L}$ dan diaduk selama 5 menit. Selanjutnya 20 $\mu \mathrm{L}$ sampel dimasukkan ke dalam injektor KCKT. Sampel dianalisis dengan menggunakan kromatografi cair kinerja tinggi (Shimadzu LC 10) pada fase diam kolom Licrospher ${ }^{\circledR} 100$ RP18 (125 x $4 \mathrm{~mm}, 5 \mu \mathrm{m})$. Sebagai fase gerak adalah Eluent A: methanol : $50 \mathrm{mM}$ natrium asetat: Teterahidrofuran (THF) dan Eluent B: 65 $\%$ metanol. Analisa ini dilakukan pada suhu $27^{\circ} \mathrm{C}$ dengan kecepatan alir $1 \mathrm{~mL} /$ menit serta dideteksi dengan detektor fluoresen pada panjang gelombang 360 dan $460 \mathrm{~nm}$. Standar asam amino yang digunakan sebagai pembanding adalah asam aspartat, glutamat, serin, histidin, glisin, arginin, alanin, tirosin, metionin, valin, isoleusin, leusin, lisin, dan fenilalanin.

Identifikasi asam lemak dengan Gas Kromatografi (GC) Varian 450. Sampel tepung dan batu didih dimasukkan ke dalam tabung, tambahkan larutan $\mathrm{NaOH}$ 0,5 N. Direfluks selama 5-10 menit. Ditambahkan larutan $\mathrm{BF}_{3}$ melalui kondensor, dididihkan selama dua menit ditambahkan 2-5 $\mathrm{mL}$ heptan dan pendidihan dilanjutkan selama satu menit. Ditambahkan $15 \mathrm{~mL} \mathrm{NaCl}$ jenuh dan dikocok selama satu menit saat larutan masih hangat.
Ditambahkan kembali $\mathrm{NaCl}$ jenuh sampai larutan heptan mencapai leher labu. Diambil satu $\mathrm{mL}$ lapisan heptan, dimasukkan ke dalam tabung reaksi bertutup sambil ditambahkan $\mathrm{Na}_{2} \mathrm{SO}_{4}$ anhidrous untuk menyerap air. Bila diperlukan larutan dapat diencerkan menjadi 5$10 \%$ sebelum diinjeksikan ke dalam GC. Sebanyak $0,5 \mathrm{~mL}$ sampel hasil sintesis metil ester asam lemak dianalisis dengan cara menyuntikkan cairan dari campuran reaksi pada gas kromatografi. Suhu kolom dijaga pada $150^{\circ}$ C selama 0,5 menit, meningkat sampai $250^{\circ} \mathrm{C}$ per menit dan dipertahankan pada suhu tersebut selama 6 menit. Suhu dari injektor dan detektor ditetapkan masing-masing pada $245^{\circ} \mathrm{C}$ dan $350^{\circ}$ C (Apriyantono dkk 1988). Persentase molar konversi produk, diidentifikasi dengan membandingkan daerah puncak standar metil ester pada retensi waktu tertentu dengan metil ester standar yang dipakai.

\section{HASIL}

Hasil uji selulase, $\alpha$-amilase dan fitase ditunjukkan pada Gambar 1. Isolat dengan nomor 6 (strain $\mathrm{B}_{7}$ ) diperoleh dari seleksi 4 isolat yang diuji. Strain nomor 6 (strain $\mathrm{B}_{7}$ ) dapat mendegradasi selulosa CMC 1\% dengan diameter zona bening terbesar (Gambar 1.A), sehingga dipakai pada penelitian. Aktivitas $\alpha$-amilase diuji secara kualitatif ditunjukkan dengan adanya aktivitas amilase dengan terlihatnya zona bening di sekitar koloni isolat nomor 6 (Gambar 1.B). Bakteri asam laktat SU-LS537 dapat mendegradasi asam fitat dengan terbentuknya zona bening di sekitar koloni bakteri (Gambar 1.C). Pada penelitian ini inokulum yang digunakan untuk fermentasi tepung adalah starter yang telah diinkubasi selama satu hari
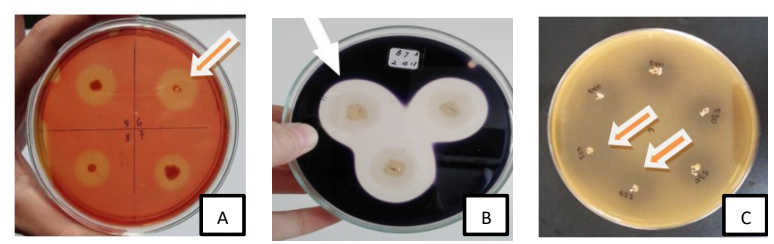

Gambar 1. Zona bening bakteri B. amyloliquifaciens B7 dalam media CMC 1\% (A) dan media pati terlarut $1 \%$ (B) serta bakteri L. plantarum SULS537 dalam media mengandung asam fitat (C). 
(24 jam) dengan jumlah sel sebesar 2,98 x $10^{7}$ dan $1,3 \times 10^{8} \mathrm{cfu} / \mathrm{mL}$ (Tabel 1.).

Gambar 2 menunjukkan hasil BLAST sekuen 16S rDNA bakteri asam laktat SU-LS537 di NCBI memiliki max score 1663 , total score 1663 , query coverage $100 \%$, E value 0,0 dan max identity $99 \%$ terhadap takson bakteri terdekatnya (L. plantarum LC042472). Hasil analisis filogenetik berdasarkan metoda Neighbor Joining menunjukkan bahwa sekuen DNA dari isolat SU-LS537 berada satu klade dengan spesies tipe L. plantarum JCM $1149^{\mathrm{T}}$ (D79210) dengan nilai bootstrap 76\%. Dengan mengacu pada data hasil BLAST dan analisis filogenetik menggunakan metoda Neighbor Joining, maka isolat SU-LS537 teridentifikasi sebagai Lactobacillus plantarum.

Hasil analisis proksimat secara umum menunjukkan peningkatan mutu tepung jali hasil fermentasi dibandingkan dengan yang tidak difermentasi, baik yang difermentasi dengan $B$. amiloliquifaciens $\mathrm{B}_{7}$, L. plantarum SU-LS537 maupun campuran keduanya (Tabel 2). Kandungan air sebelum fermentasi tinggi 10,23\% tetapi setelah fermentasi $B$. amiloliquifaciens $\mathrm{B}_{7}$, L. plantarum SU-LS537 dan campuran $B$. amiloliquifaciens $\mathrm{B}_{7}$ dan $L$. plantarum SULS537 terjadi penurunan masing-masing

Tabel 1. Pertumbuhan dari bakteri B. amiloliquifaciens $\mathrm{B}_{7}$ dan berdasarkan kerapatan optik dan jumlah sel dalam media pertumbuhan

\begin{tabular}{|c|c|c|c|c|c|c|}
\hline \multirow{2}{*}{ Parameter } & \multicolumn{2}{|c|}{ Starter $B$. amiloliquifacie } & \multirow{2}{*}{$\frac{\text { B7 (Hari) }}{3}$} & \multicolumn{3}{|c|}{ L.plantarum SU-LS537 (Hari) } \\
\hline & 1 & 2 & & 1 & 2 & 3 \\
\hline OD $\lambda 600 \mathrm{~nm}$ & 1.4 & 2.4 & 3.9 & 3.37 & 4.38 & 4.5 \\
\hline $\begin{array}{l}\text { Jumlah sel } \\
\mathrm{pH}\end{array}$ & $\begin{array}{r}2.98 \times 10^{7} \\
6.38\end{array}$ & $\begin{array}{c}1.5 \times 10^{7} \\
5.85\end{array}$ & $\begin{array}{c}3 \times 10^{7} \\
6.7\end{array}$ & $\begin{array}{c}1.3 \times 10^{8} \\
4.35\end{array}$ & $\begin{array}{c}4.8 \times 10^{7} \\
4.42\end{array}$ & $\begin{array}{c}2.3 \times 10^{7} \\
4.11\end{array}$ \\
\hline
\end{tabular}

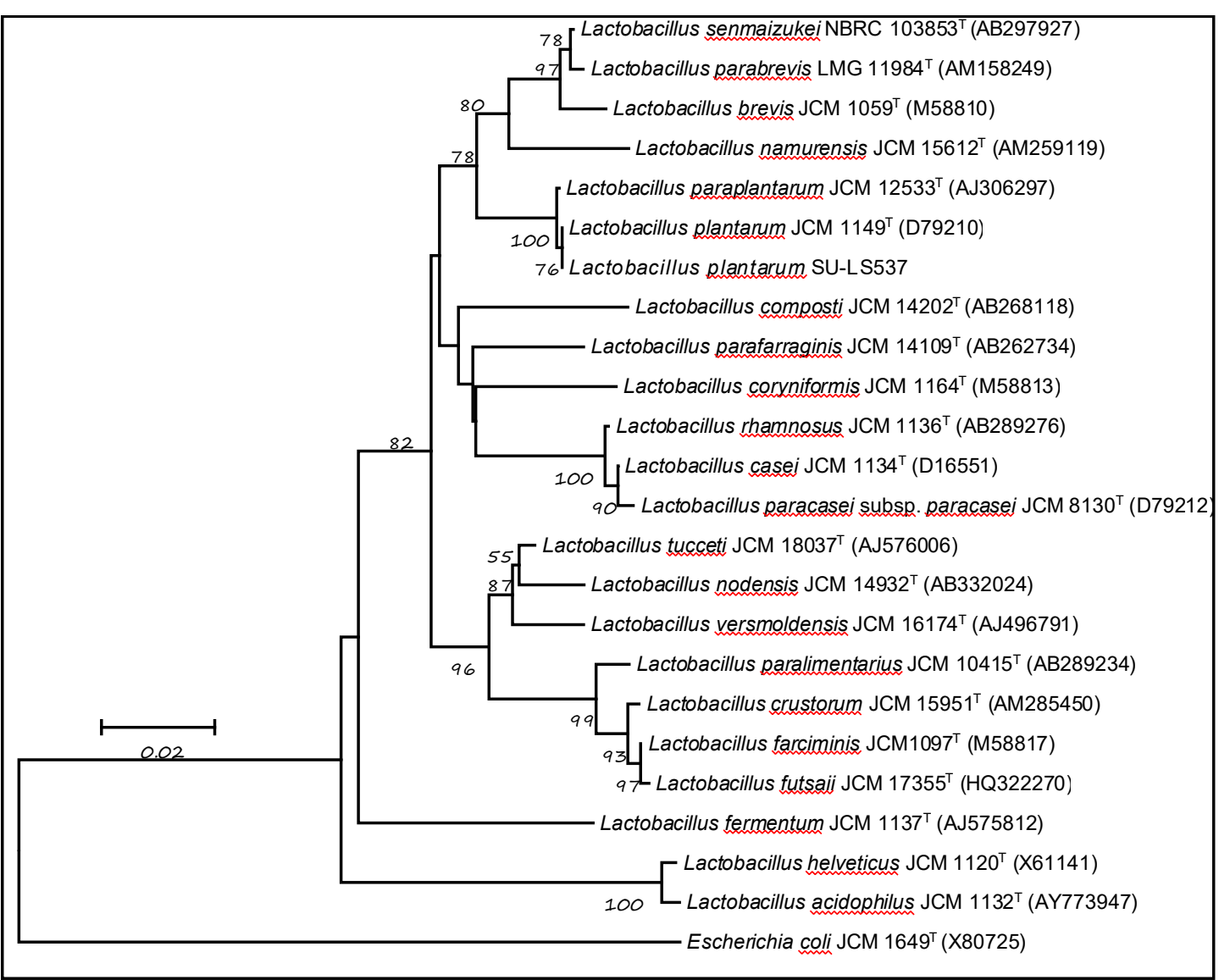

Gambar 2. Pohon filogenetik sekuen 16S rDNA Lactobacillus plantarum SU-LS537 menggunakan metode Neighbor Joining dengan 100 kali ulangan dan Escherichia coli JCM $1649^{\mathrm{T}}(\mathrm{X} 80725)$ sebagai outgroup. 
5,58\%, 7,27\% dan 6,46\%. Kandungan abu terjadi peningkatan dari sebelum fermentasi sebesar $0,27 \%$ dan setelah difermentasi masingmasing $0,95 \%, 0,84 \%, 0,96 \%$. Kandungan lemak pada bahan yang difermentasi dengan $B$. amiloliquifaciens $\mathrm{B}_{7}$ dan $L$. plantarum SULS537 terjadi penurunan dibanding dengan hasil yang tidak difermentasi. Pada bahan yang dengan difermentasi campuran $B$. amiloliquifaciens $\mathrm{B}_{7}$ dan L. plantarum SU-LS537 terjadi peningkatan kadar lemak. Kandungan protein terjadi peningkatan setelah difermentasi menjadi sebesar masing-masing 14,72\%, 14,42\%, 14,64\% dibandingkan sebelum fermentasi sebesar 13,98\%. Kandungan karbohidrat terjadi peningkatan setelah difermentasi masing-masing menjadi 77,01\%, 75,90\%, 75,32\% dibandingkan sebelum fermentasi sebesar $73,57 \%$. Kandungan serat pangan pada tepung sebelum fermentasi sebesar $6,84 \%$ terjadi peningkatan setelah difermentasi dengan $B$. amiloliquifaciens $\mathrm{B}_{7}$ menjadi sebesar 7,55\% tetapi fermentasi dengan L. plantarum SULS537 dan campuran antara $B$. amiloliquifaciens $\mathrm{B}_{7}$ dan L. plantarum SU-LS537 terjadi penurunan masing-masing menjadi $2,46 \%$ dan $4,27 \%$.
Hasil analisis derajat putih tepung hasil fermentasi berkisar 81,73 - 85,50\%, tanpa difermentasi tidak dianalisa (Tabel 3). Tepung jali tanpa fermentasi tidak mengandung gluten dan asam fitat sehingga tidak dianalisa pada tepung hasil fermentasinya. Kandungan vitamin E tanpa fermentasi sebesar $143,68 \mathrm{mg} / 100 \mathrm{~g}$ setelah difermentasi terjadi kenaikkan menjadi masing-masing $185,31 \mathrm{mg} / 100 \mathrm{~g}, 179,73 \mathrm{mg} / 100 \mathrm{~g}$ $\mathrm{mg} / 100 \mathrm{~g}, 160,86 \mathrm{mg} / 100 \mathrm{~g}$. Kandungan vitamin $\mathrm{B}_{6}$ dan vitamin $B_{12}$ hasil fermentasi terjadi penurunan. Kandungan mineral kalsium setelah fermentasi terjadi kenaikan dari sebelum fermentasi sebesar $1,84(\mathrm{mg} / 100 \mathrm{~g})$ setelah fermentasi masingmasing menjadi $42,73 \mathrm{mg} / 100 \mathrm{~g}, 35,26 \mathrm{mg} / 100 \mathrm{~g}$, $38,98 \mathrm{mg} / 100 \mathrm{~g}$. $\mathrm{pH}$ setelah fermentasi terjadi penurunan berkisar 4,67 - 5,89 yang semula sebelum fermentasi sebesar 6,7.

Gambar 3 menunjukkan hasil analisis sembilan jenis asam amino non-esensial terdiri dari asam aspartat, asam glutamat, serin, glisin, arginin, alanin, prolin, tirosin dan sistein. Hasil analisis asam amino dari jali yang tidak difermentasi, yang difermentasi dengan $B$. amyloliquifaciens $\mathrm{B}_{7}$, difermentasi dengan $L$.

Tabel 2. Hasil analisis proksimat tepung jali tanpa dan dengan difermentasi

\begin{tabular}{llcccc}
\hline Jenis Analisis & \multicolumn{1}{c}{ Metode } & $\begin{array}{c}\text { Tepung tanpa } \\
\text { fermentasi }\end{array}$ & $\begin{array}{c}\text { Tepung+ } \\
\text { Selulolitik }\end{array}$ & Tepung+BAL & $\begin{array}{c}\text { Tepung + } \\
\text { Selulolitik +BAL }\end{array}$ \\
\hline Kadar Air (\%) & $\begin{array}{l}\text { Gravimetri } \\
\text { (AOAC, 1970) }\end{array}$ & 10,23 & 5,58 & 7,27 & 6,46 \\
Kadar Abu (\%) & $\begin{array}{l}\text { Gravimetri } \\
\text { (AOAC, 1970) }\end{array}$ & 0,27 & 0,95 & 0,84 & 0,96 \\
Kadar Lemak (\%) & Soxhlet (1941) & 1,95 & 1,74 & 1,57 & 2,62 \\
Kadar Protein (\%) & Kjeldahl & 13,98 & 14,72 & 14,42 & 14,64 \\
Karbohidrat (\%) & By Different & 73,57 & 77,01 & 75,9 & 75,32 \\
Serat Pangan (\%) & Enzimatik & 6,84 & 7,55 & 2,46 & 4,27 \\
\hline
\end{tabular}

Tabel 3. Hasil analisis derajat putih, gluten, asam fitat, vitamin $E$, vitamin $B_{6}$, vitamin $B_{12}$, garam mineral kalsium, $\mathrm{pH}$ dan berat akhir tepung jali tanpa dan dengan difermentasi

\begin{tabular}{llcccc}
\hline \multicolumn{1}{c}{ Jenis Analisis } & \multicolumn{1}{c}{ Metode } & $\begin{array}{c}\text { Tepung tanpa } \\
\text { fermentasi }\end{array}$ & $\begin{array}{c}\text { Tepung+ } \\
\text { Selulolitik }\end{array}$ & $\begin{array}{c}\text { Tepung+ } \\
\text { BAL }\end{array}$ & $\begin{array}{c}\text { Tepung + } \\
\text { Selulolitik+BAL }\end{array}$ \\
\hline Derajat Putih (\%) & Whiteness Meter & - & 85,5 & 81,73 & 84,2 \\
Gluten (\%) & Gravimetri & 0 & - & - & - \\
Asam Fitat & KCKT & ttd & - & - & - \\
Vitamin E (mg/100g) & KCKT & 143,68 & 185,31 & 179,73 & 160,86 \\
Vitamin B $_{6}(\mathrm{mcg} / 100 \mathrm{~g})$ & KCKT & 6,84 & 1,32 & 2,38 & 1,7 \\
Vitamin $\mathrm{B}_{12}(\mathrm{mcg} / 100 \mathrm{~g})$ & KCKT & 2,81 & 1,42 & 1,12 & 1,07 \\
Kalsium (mg/100g) & AAS & 1,84 & 42,73 & 35,26 & 38,98 \\
pH & pH-meter & 6,7 & 5,89 & 5,4 & 4,67 \\
Berat akhir $(\mathrm{g})$ & neraca & 200 & 177,81 & 182,45 & 180,88 \\
\hline
\end{tabular}


plantarum SU-LS537 dan fermentasi campuran dari $B$. amyloliquifaciens $\mathrm{B}_{7}$ dan difermentasi dengan $L$. plantarum SU-LS537 secara umum terjadi peningkatan kandungan asam aminonya. Diantara dari ketiga perlakuan hasil fermentasi kandungan asam amino non-esensial yang mengalami peningkatan adalah hasil fermentasi dengan L. plantarum SU-LS537. Kandungan asam amino glutamat sangat tinggi, glutamat merupakan sumber nitrogen yang baik. Kandungan asam amino non-esensial tepung hasil fermentasi lebih tinggi dibandingkan dengan yang tidak difermentasi.

Gambar 4 menunjukkan hasil analisis delapan jenis asam amino esensial terdiridari histidin, treonin, valin, metionin, isoleusin, leusin, fenilalanin dan lisin di tepung jali. Hasil analisis asam amino dari jali yang tidak difermentasi, yang difermentasi dengan $B$. amyloliquifaciens $\mathrm{B}_{7}$ dan difermentasi dengan $L$. plantarum SU-LS537 dan fermentasi campuran dari $B$. amyloliquifaciens $\mathrm{B}_{7}$ dan difermentasi dengan L. plantarum SU-LS537 secara umum terjadi peningkatan kandungan asam aminonya kecuali kadar asam amino metionin yang difermentasi dengan B. amyloliquifaciens terjadi penurunan dari $0,128 \%$ menjadi $0,121 \%$, tetapi fermentasi dengan bakteri $L$. plantarum SULS537 dan campuran B. amyloliquifaciens $\mathrm{B}_{7}$ dan L. plantarum SU-LS537 kadar asam amino metionin tetap meningkat. Kandungan asam

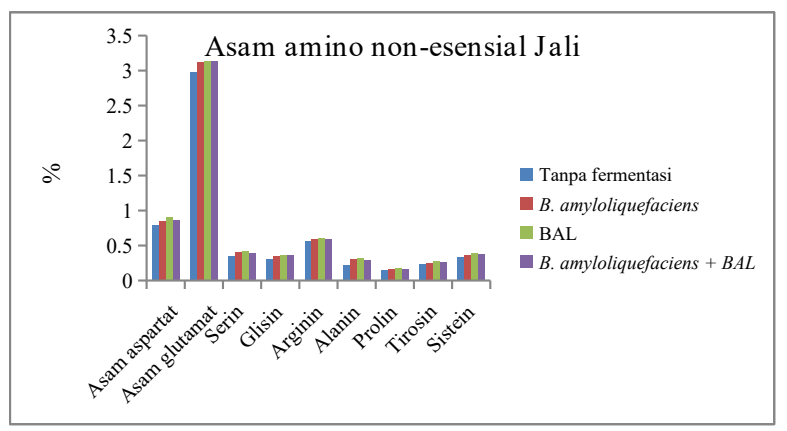

Gambar 3. Kandungan asam amino non-esensial dari jali amino esensial tepung hasil fermentasi ada peningkatan dibandingkan dengan tepung yang tidak difermentasi.

Hasil analisis asam lemak esensial pada tepung jali yang difermentasi dengan $B$. amiloliquifaciens $\mathrm{B}_{7}$ dan difermentasi dengan $L$. plantarum SU-LS537 terjadi penurunan dibanding tanpa fermentasi. Sedangkan hasil analisis asam lemak non-esensial pada tepung jali hasil fermentasi dengan $B$. amiloliquifaciens $\mathrm{B}_{7}$ dan hasil fermentasi dengan $L$. plantarum SU-LS537 terjadi peningkatan dibanding tanpa fermentasi (Tabel 4).

\section{PEMBAHASAN}

Produksi pangan terutama beras belum dapat mengimbangi peningkatan jumlah penduduk, oleh karena itu diperlukan suatu usaha diversifikasi pangan untuk mengatasi hal tersebut. Jali dapat menjadi pangan alternatif sebagai salah satu usaha diversifikasi pangan karena jali memiliki nilai gizi yang baik. Kadar air merupakan parameter penting untuk produk tepung, karena keberadaan air yang terlalu tinggi akan menyebabkan rendahnya umur daya simpan (Rao et al. 2013), penelitian ini sesuai dengan standar SNI yang diterapkan kurang dari 14\% (BSN 2011). Kadar abu pada penelitian hasil fermentasi lebih besar dari tanpa fermentasi. Semakin besar kadar abu

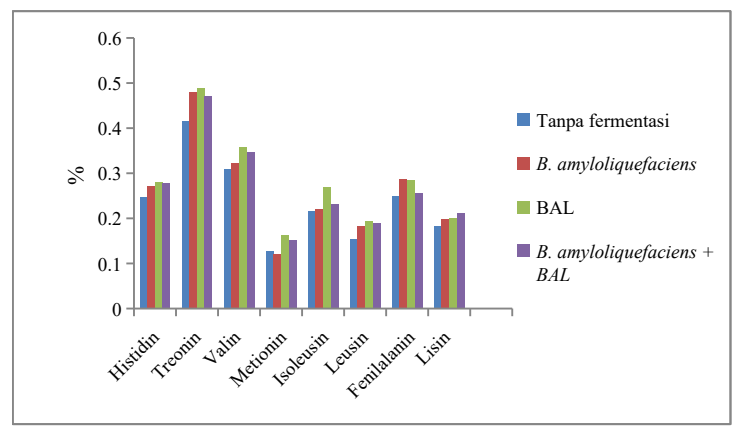

Gambar 4. Kandungan asam amino esensial dari jali

Tabel 4. Hasil analisis asam lemak esensial dan non-esensial tepung jali yang tanpa dan dengan difermentasi

\begin{tabular}{lccccc}
\hline \multicolumn{1}{c}{ Asam lemak (\%) } & Metode & $\begin{array}{c}\text { Tepung tanpa } \\
\text { fermentasi }\end{array}$ & $\begin{array}{c}\text { Tepung }+ \\
\text { amiloliquifaciens }\end{array}$ & $\begin{array}{c}\text { B. } \\
\text { B7 }\end{array}$ & $\begin{array}{c}\text { Tepung }+ \\
\text { plantarum }\end{array}$ \\
\hline SuU-LS537 \\
\hline Asam lemak esensial & GC & 0,68 & 3,19 & 4,71 \\
\hline
\end{tabular}


suatu bahan makanan, menunjukkan semakin tinggi mineral yang dikandung (Bassey et al. 2013). Fermentasi telah dilaporkan efektif dalam menurunkan tingkat faktor antinutritional dalam sereal dan meningkatkan daya cerna pati dan protein, keseimbangan asam amino serta nilai gizi (Belton \& Taylor 2004). Asam fitat telah dikenal sebagai penghambat utama penyerapan mineral seperti kalsium, magnesium, zat besi dan seng. Dengan adanya enzim fitase yang dihasilkan dari mikroba maka mineralmineral yang dikhelat oleh asam fitat dapat terurai (Inyang \& Zakari 2008). Pada penelitian ini kadar lemak hasil fermentasi dengan B. amyloliquifaciens $\mathrm{B}_{7}$ dan difermentasi dengan $L$. plantarum SULS537 terjadi penurunan, hal ini menandakan bahwa tepung hasil fermentasi baik untuk program diet dan dapat juga dikaitkan dengan adanya aktivitas enzim lipolitik yang terjadi selama fermentasi (Uvere et al. 2010). Enzim lipolitik adalah enzim yang mengkatalis lemak (lipid) menjadi asam lemak dan gliserol (Lass et al. 2006). Tingginya kandungan protein setelah fermentasi disebabkan oleh pertumbuhan mikroba, yang menyumbangkan protein lebih banyak ke dalam substrat karena sel mikroba mengandung protein yang cukup tinggi yaitu $40-50 \%$. Peningkatan kandungan protein setelah fermentasi ini dapat dikatakan sebagai proses "protein encrihment" yang berarti proses pengayaan protein dari mikroorganisme tertentu proses ini sama dengan pada pembuatan protein sel tunggal antara sel mikroba yang tumbuh dengan sisa substratnya tidak dipisahkan (Rusli 2011; Akintomide \& Antai 2012).

Tepung jali hasil fermentasi dengan bakteri selulolitik kadar serat pangannya meningkat dibanding tanpa fermentasi. Pentingnya serat pangan telah menyebabkan perkembangan pasar yang besar, potensial untuk produk dan bahan kaya serat dan dalam beberapa tahun terakhir, ada kecenderungan untuk menemukan sumber serat pangan baru yang dapat digunakan dalam industri pangan (Chau \& Huang 2003). Peran utama serat dalam makanan ialah pada kemampuannya mengikat air, selulosa dan pektin, dengan adanya serat, membantu mempercepat sisa-sisa makanan melalui saluran pencernaan untuk diekskresikan keluar (Mudgil 2017). Serat pangan memberikan manfaat secara fisiologi yaitu sebagai laksansia, kontrol kolesterol darah dan kontrol glukosa darah dan dapat mengurangi risiko kanker kolon juga membantu mengurangi terjadinya obesitas dan penyakit jantung (Sharifi-Rad et al. 2020).

Hasil derajat putih tepung jali fermentasi berkisar 81,73\% - 85,5\% (Tabel 3). Fermentasi menggunakan $B$. amyloliquifaciens $\mathrm{B}_{7}$ menunjukkan derajat putih paling tinggi. Derajat putih merupakan pengukuran yang umum dilakukan untuk menentukan kecerahan warna tepung baik secara tradisional maupun secara fermentasi. Kecerahan warna menunjukkan warna gelap hingga putih terang dengan nilai berkisar 0 100\% (Windrati 2014).

Menurut Azeke et al. (2011) di dalam beras, jagung, millet, sorgum dan gandum mengandung asam fitat berkisar antara 5,6 dan $6,2 \mathrm{mg} / \mathrm{g}$ yang bersifat sebagai senyawa anti-nutrisi. Asam fitat (myoinositol hexaphosphate) dapat mengikat mineral esensial seperti $\mathrm{Ca}, \mathrm{Mg}, \mathrm{Fe}$ dan $\mathrm{Zn}$ dan dapat mengikat asam amino dan protein (Pallauf \& Rimbach 1996) sehingga dapat menyebabkan mineral, asam amino dan protein tidak dapat diserap oleh usus manusia dan ternak non-ruminansia. Padahal zat tersebut sangat dibutuhkan pada proses metabolisme tubuh, kekurangan mineral tersebut dapat menyebabkan timbulnya berbagai kelainan (Liu et al. 1997). Satu cara untuk meningkatkan efisiensi pemanfaatan unsur $\mathrm{P}$ dari asam fitat adalah dengan penggunaan enzim fitase. Fitase (EC 3.1.3.8; myo-inositol hexakisphosphate phosphohydrolase) merupakan kelompok enzim phosphatase yang mampu menghidrolisis asam fitat menjadi monophosphate anorganik, myoinositol phosphate rendah (lower myo-inositol phosphate), dan myo-inositol bebas (Kerovuo 2000; Quan et al. 2002). Enzim ini dapat dihasilkan oleh mikroorganisme (bakteri, jamur, yeast), jaringan hewan dan tanaman. Pada biji legum dan sereal yang berkecambah, fitat dihidrolisis oleh fitase untuk menyediakan unsur P (Miswar 2012). Hasil penelitian dari Azeke et al. (2005) melaporkan adanya penurunan yang signifikan dalam kandungan asam fitat kacang ubi dari Afrika setelah difermentasi oleh $L$. plantarum menjadi enzim fitase. Fitase dalam diet dapat meningkatkan terhadap penyerapan mineral, sehingga dapat 
memberikan perlindungan terhadap timbulnya kanker, dapat digunakan terapi terhadap diabetes mellitus, aterosklerosis dan penyakit jantung koroner, dapat mengurangi pembentukan batu ginjal, HIV-1 dan toksisitas logam berat (Kumar et al. 2010).

Pada penelitian ini kandungan vitamin $\mathrm{E}$ dengan fermentasi terjadi kenaikkan dibanding tanpa fermentasi. Vitamin E (tokoferol) merupakan antioksidan yang larut dalam lemak, vitamin ini dikenal sebagai pelindung tubuh terhadap racun dari polusi udara, sindrom pramenstruasi, gangguan mata seperti katarak, penyakit saraf seperti penyakit Alzheimer, dan diabetes. Pada penelitian ini tepung jali tanpa dan dengan fermentasi mengandung kandungan vitamin B6 dan vitamin B12. Menurut Bender (2003) vitamin $B_{6}$ dan vitamin $B_{12}$ termasuk ke dalam mikronutrien, diperlukan oleh tubuh dalam jumlah sedikit namun fungsinya cukup vital. Vitamin $\mathrm{B}_{6}$ (Piridoksin) untuk proses metabolisme protein dan karbohidrat, pembentukan sel darah merah dan beberapa zat kimia penting pada otak. Piridoksin juga mempengaruhi fungsi imunitas dan aktivitas hormon steroid, insomnia, anemia, depredi, lidah halus, pecah-pecah di sudut bibir, mudah marah, serta linu otot. Vitamin $\mathrm{B}_{12}$ (Sianokobalamin) membantu mengatur pem-bentukan sel darah merah dalam tubuh, pemecah asam lemak dan asam amino untuk menghasilkan energy. Kekurangan vitamin $\mathrm{B}_{6}$ menyebabkan masalah yang melibatkan penyakit jantung, osteoporosis, dan diabetes (Mooney et al. 2009).

Pada penelitian ini kandungan mineral kalsium dengan fermentasi terjadi kenaikkan yang sangat besar (Tabel 3). Dengan adanya enzim fitase yang dihasilkan dari mikroba dapat mengurai mineral-mineral yang dikhelat oleh asam fitat dalam bahan jali, salah satunya mineral kalsium. Seperti diketahui asam fitat (myoinositol hexaphosphate) mengikat beberapa mineral esensial seperti $\mathrm{Ca}, \mathrm{Mg}, \mathrm{Fe}$ dan $\mathrm{Zn}$ dan juga dapat mengikat asam amino serrta protein (Pallauf \& Rimbach 1996). Mineral kalsium termasuk mineral makro yaitu mineral yang ada di dalam tubuh penting untuk menjaga kesehatan tulang dan gigi, proses kontraksi dan relaksasi otot, pembekuan darah, pengaturan tekanan darah dan sistem kekebalan tubuh
(Romito 2019).

Pada penelitian ini menggunakan starter masing-masing $B$. amiloliquifaciens $\mathrm{B}_{7}$ dan $L$. plantarum SU-LS537 difermentasi 24 jam. Penggunaan kultur starter (umumnya diproduksi menggunakan fermentasi) bisa menjadi metode alternatif (Onwurafor et al. 2014). Aplikasi fermentasi dalam pengolahan beberapa sereal dan kacang-kacangan yang digunakan dalam makanan pelengkap telah terbukti mengurangi anti-nutrisi dan meningkatkan keamanan produk. Fermentasi telah dianggap sebagai cara yang efektif untuk mengurangi risiko kekurangan mineral di antara populasi, terutama di negara berkembang di mana sereal dan atau kacangkacangan yang tidak diolah sangat banyak dikonsumsi (Kumar et al. 2010). Akhir-akhir ini telah banyak makanan yang diproduksi menggunakan teknologi fermentasi baik di rumah tangga, produksi industri kecil, menengah dan besar sampai tingkat komersial. Melalui proses fermentasi tercipta rasa yang unik, baik tekstur maupun sifat yang timbul jauh lebih baik (Wizna et al. 2012; Onwurafor et al. 2014). Menurut Lawal et al. (2009) fermentasi meningkatkan kecernaan makanan dan kualitas gizi dari fermentasi jagung (Zea mays), sorgum (Sorghum biclolor) atau millet (Pennisetum typhoides) dan beberapa kacangkacangan seperti kacang tunggak, bambara kacang tanah dan kacang kedelai telah difermentasi untuk melengkapi makanan yang berkualitas gizinya.

Pada penelitian ini dianalisa kandungan asam amino non-esensial dan esensial tanpa dan dengan fermentasi. Hasil penelitian yang dilakukan Pranoto et al. (2013) menyebutkan proses fermentasi pada tepung sorgum dapat memperbaiki keseimbangan asam amino dalam tepung. Hasil analisis dari jali yang tidak difermentasi, yang difermentasi dengan $B$. amyloliquifaciens $\mathrm{B}_{7}$ dan difermentasi dengan L. plantarum SU-LS537 dan difermentasi campuran dari $B$. amyloliquifaciens $\mathrm{B}_{7}$ dan $L$. plantarum SU-LS537 menghasilkan sembilan jenis asam amino non-esensial yaitu Asam Aspartat, Asam Glutamat, Serin, Glisin, Arginin, Alanin, Prolin, Tirosin, Sistein dan delapan jenis asam amino esensial yaitu Histidin, Treonin, Valin, Metionin, Isoleusin, 
Leusin, Fenilalanin, Lisin, ditunjukan pada Gambar 3 dan 4. Asam amino tersebut berperan sangat penting menjaga jantung tetap sehat, membentuk senyawa kimia yang bertugas untuk mengirimkan sinyal di sel-sel otak, dapat memperbaiki jaringan tubuh yang rusak, dapat membentuk antibodi, dapat menyeimbangkan kerja hormon, enzim dan kadar cairan tubuh, meningkatkan daya ingat dan stamina, memperkuat rambut, meningkatkan massa otot.

Pada penelitian ini dianalisa kandungan asam lemak non-esensial dan esensial tanpa dan dengan fermentasi. Asam lemak tidak jenuh yang memiliki ikatan rangkap sebagai asam lemak esensial yaitu asam lemak yang tidak dapat disintesis sendiri (Pasquale 2009). Sumber asam lemak yang berasal dari tumbuhan biasanya ditemukan dalam bentuk cair seperti asam linoleat, asam oleat, dan asam arakhidonat. Senyawa-senyawa ini dibutuhkan tubuh kita dan berperan penting dalam berbagai fungsi fisiologis, terutama dalam pembentukan struktur membran sel dan dapat mencegah penyakit jantung koroner. Manusia memerlukan asam linoleat kurang lebih 2\% dari makanan berkalori setiap harinya (Hartono 2015). Tubuh kita tidak dapat memproduksi asam lemak esensial, sehingga harus mendapatkannya dari sumber makanan. Tepung jali dapat menghasilkan asam lemak esensial yang merupakan asam lemak mono tidak jenuh berfungsi mengatur berbagai fungsi tubuh termasuk tekanan darah, kekentalan darah, kekebalan tubuh serta sitem saraf (Bruno 2005). Tubuh kita dapat memproduksi asam lemak non-esensial yaitu lemak poli tidak jenuh memiliki efek positif pada berat badan, kesehatan jantung, keseimbangan gula darah dan berpotensi dapat meringankan gejala menopause (Norton 2013).

Pengaruh fermentasi jali dengan B. subtilis BCRC 14718 dan L. plantarum menghasilkan antioksidan, hal ini menunjukkan bahwa proses fermentasi memungkinkan makanan berbasis sereal dapat berkontribusi terhadap kesehatan dan gizi konsumen (Wang et al. 2014). Produk tepung hasil fermentasi dapat diaplikasikan dalam produk pangan sesuai dengan fungsinya setelah melalui tahapan penelitian lebih mendalam (Kustyawati dkk. 2013). Menurut hasil penelitian Steinkraus (2006) peran fermentasi dalam pengolahan pangan adalah pengayaan substrat sebagai bahan pangan biologis seperti vitamin, protein, asam amino esensial dan asam lemak terbukti. Semua konsumen saat ini telah memenuhi sebagian besar kebutuhan nutrisinya melalui makanan dan minuman yang difermentasi. Ini kemungkinan besar akan berkembang di abad ke-21, ketika populasi dunia mencapai 8 hingga 12 miliar. Sehingga dapat mendorong peningkatan pembangunan agroindustri tepung-tepungan nasional, terutama peningkatan produksi tepung fermentasi. Komitmen Pemerintah dalam mengembangkan pangan non beras dan non terigu dapat segera berhasil secara nasional dengan baik dan lancar. Gerakan ini merupakan salah satu upaya untuk mewujudkan peningkatan diversifikasi pangan salah satu kunci sukses pembangunan pertanian di Indonesia.

\section{KESIMPULAN}

Proses fermentasi substrat semi padat menggunakan bakteri selulolitik \& amilolitik $B$. amiloliquifaciens $\mathrm{B}_{7}$, bakteri asam laktat dari $L$. plantarum SU-LS537 dan campuran dari $B$. amiloliquifaciens dan L. plantarum SU-LS537 cukup meningkatkan kualitas tepung jali yang meliputi nilai nutrisi kadar (abu, protein, karbohidrat), serat pangan, kalsium, asam amino esensial dan non-esensial, asam lemak esensial dan non-esensial.

\section{UCAPAN TERIMA KASIH}

Penelitian ini didanai oleh DIPA tematik Pusat Penelitian Biologi LIPI. Terimakasih disampaikan kepada sdri Khairunisa atas asistensinya di laboratorium.

\section{KONTRIBUSI PENULIS}

YS., sebagai kontributor utama dan S., sebagai kontributor anggota yaitu: Sulistiani.

\section{DAFTAR PUSTAKA}

Afiati, F., NA Widad, \& Kusmiati 2015. Pengaruh Antioksidan Eksopolisakarida dari Tiga Galur Bakteri Asam Laktat pada 
Sel Darah Domba Terinduksi tert-Butil Hidroperoksida (t-BHP). Jurnal Biologi Indonesia. 11 (2): 225 - 232.

Akintomide, MJ. \& SP. Antai. 2012. Protein Enrichment of Irish potato (Solanium tuberosium) peels through Solid Substrate Fermentation by Saccharomyces cerevisiae and Aspergillus niger. IOSR Journal of Environmental Science, Toxicology and Food Technology. 1(5): 15-19.

Apriyantono, A., D. Fardiaz, NL. Puspitasari, Sedarnawati \& S. Budiyanto. 1989. Petunjuk Laboratorium Analisa Pangan. Institut Pertanian Bogor, Bogor.

Azeke, MA., B. Fretzdorff, H. Buening-Pfaue, W. Holzapfel \& T. Betsche. 2005. Nutritional value of African yambean (Sphenostylis stenocarpa L): improvement by lactic acid fermentation. Journal of the Science of Food and Agriculture. 85(6): 963-970.

Azeke, MA., SJ. Egielewa, MU. Eigbogbo \& IG. Ihimire. 2011. Effect of germination on the phytase activity, phytate and total phosphorus contents of rice (Oryza sativa), maize (Zea mays), millet (Panicum miliaceum), sorghum (Sorghum bicolor) and wheat (Triticum aestivum). Journal of Food Science Technology. 48(6): 724-729.

Badan Standardisasi Nasional. 2011. Tepung mocaf sebagai bahan makanan. SNI 017622-2011. BSN. Jakarta.

Bassey, F., KH. McWatters, CA. Edem \& CMA. Lwegbue. 2013. Formulation and nutritional evaluation of weaning food processed from cooking banana, supplemented with cowpea and peanut. Food Science and Nutrition 1(5):384-391.

Belton, P. \& JRN. Taylor. 2004. Sorghum and millets: Protein sources for Africa. Trends in Food Science \& Technology. 15(2): 94 $-98$.

Bender, DA. 2003. Nutritional Biochemistry of the Vitamins. Second Edition. Cambridge University Press, New York.

Bhandari, SR., SK. Park, YC. Cho \& YS. Lee. 2012. Evaluation of phytonutrients in Adlay (Coix lacrymajobi L.) seeds. African Journal Biotechnology 11(8): 1872-1878.
Bruno, G. 2005. Essential \& Non-Essential Fatty Acids. Literature Education Series On Dietary Supplements. Huntington College of Health Sciences.

Chang, HC., YC. Huang \& WC. Hung. 2003. Antiproliferative and chemo-preventive effects of adlay seed on lung cancer in vitro and in vivo. Journal of Agricultural and Food Chemistry. 51(12): 3656-3660.

Chau, CFi \& YL. Huang. 2003. Comparison of the chemical composition and physicochemical properties of different fibers prepared from the peel of Citrus sinensis L. Cv. Liucheng. Journal of Agricultural and Food Chemistry. 51(9): 2615-2618.

Darmawan, DA. 2015. Arah dan Kebijakan Bagi Penguatan Ketahanan Pangan Pendorong Pengurangan Kemiskinan. Dalam Purwanto (Editor). Model Pengurangan Kimiskinan melalui Penguatan Ketahanan Pangan. LIPI Press. 49-70.

Efron, B. 1979. Bootstrap methods: another look at the jackknife. The annals of Statistics 7: 126.

Elizabeth, R. 2011. Strategi Pencapaian Diversifikasi dan Kemandirian Pangan: Antara Harapan dan Kenyataan. Iptek Tanaman Pangan 6(2) : 230-242.

Gan, Ren-You, Hua-Bin Li, A. Gunaratne, Zhong-Quan Sui \& H. Corke. 2017. Effects of Fermented Edible Seeds and Their Products on Human Health: Bioactive Components and Bioactivities. Comprehensive Reviews in Food Science and Food Safety. 16(3): 489-531.

Handayani, R. 2018. Fermentasi Jali Menggunakan Bakteri Selulolitik dan Bakteri Asam Laktat untuk Pembuatan Tepung. Jurnal Biologi Indonesia 14 (1): 81-89.

Hartono, J. 2015. Fungsi Lemak dan Turunan Lemak (Lemak Sederhana, Lemak Campuran |esensial / non-esensial, Turunan Lemak). www.kehidupankita.com» Biology

Hsu, HY., BF. Lin, JY. Lin, CC. Kuo \& W. Chiang. 2003. "Suppression of allergic reactions by dehulledadlay inassociation with the balance of Th1/Th2 cell responses" Journal of Agricultural and 
Food Chemistry. 51: 3763-3769.

Inyang, CU. \& Zakari, UM. 2008. Effect of Germination and Fermentation of Pearl Millet on Proximate, Chemical and Sensory Properties of Instant "Fura"- A Nigerian Cereal Food. Pakistan journal of Nutrition. 7(1): 9-12.

Juhaeti, T. 2015. Jali (Coix lacryma-jobi L.; Poaceae) untuk Diversifikasi Pangan: Produktifitas pada Berbagai Taraf Pemupukan. Berita Biologi. 14(2): 163168.

Kerovuo, J. 2000. A novel phytase from Bacillus: Characterization and production of the enzyme. Dissertation, University of Helsinki, Finland.

Kumar, V., AK. Sinha, HPS. Makkar \& K. Becker. 2010. Dietary Roles of Phytate And Phytase In Human Nutrition: A Review. Food Chemistry. 120(4): 945959.

Kustyawati, ME. M. Sari \& T. Haryati. 2013. Efek Fermentasi Dengan Saccharomyces cerevisiae Terhadap Karakteristik Biokimia Tapioka. Agritech. 33(3): 20-35.

Lass, A., R. Zimmermann, G. Haemmerle, M. Riederer, G. Schoiswohl \& M. Schweiger. 2006. Adipose triglyceride lipase-mediated lipolysis of cellular fat stores is activated by CGI-58 and defective in ChanarinDorfman syndrome. Cell Metab. 3(5): 309 -319 .

Lawal, AK., OB. Oyedoyin \& OO. Olatunji. 2009. Fate of pathogenic bacteria during the fermentation of cereal porridge ("Ogi")- A weaning food formula. Nigerian Food Journal. 27 (1) : 19-24.

Liu, J., DR. Ledoux \& TL. Veum. 1997. In vitro procedure for predicting the enzymatic dephosphorylation of phytate in corn-soybean meal diets for growing swine. Journal of Agriculture and Food Chemitry. 45(7): 2612-2617.

Manosroi, A., M. Sainakham, C. Chankhampan, W. Manosroi \& J. Manosroi. 2015. In vitro anti-cancer activities of Job's tears (Coix lachrymajobi Linn.) extracts on human colon adenocarcinoma. Saudi Journal of Biological Sciences. doi:10. 1016/ j.sjbs.2015.03.008.

Marco, K. \& K. Wunwisa. 2012. "The Use of Job's Tear (Coix lacryma-jobi L.) Flour to Substitute Cake Flour in Butter Cake". Faculty of Biotechnology. Assumption University, Bangkok, Thailand.

Miswar, M. 2012. Isolasi Dan Purifikasi Fitase dari Kotiledon Kedelai [Glycine $\max (\mathrm{L}$.) Merr.] Hasil Perkecambahan. ojs.unud.ac. id/index.php/mip/article/download/1706/ 1020.

Mooney, S., JE. Leuendorf, C. Hendrickson \& H. Hellmann. 2009. Vitamin B6: a long known compound of surprising complexity. Molecules. 14(1): 329-351.

Mudgil, D. 2017. CHAPTER 3. The Interaction Between Insoluble and Soluble Fiber. In book: Dietary Fiber for the Prevention of Cardiovascular Disease pp. 35-59.

Mustarichie, R., Z. Udin, J. Levita, I. Musfiroh \& I. Zulfricar. 2011. Activity of Leaf Extracts of Coix lachryma LINN. and Asparagus cochinchinensis LINN. As Breast Anticancer Drugs. Medical and Health Science Journal. $9:$ 47-57.

Norton, JR. 2013. Fats Explained: Non-essential Fatty Acids - Omega-5, Omega-7, Omega-9. http://edpro.wpengine.com.

Nurmala, T. 2003. Prospek jewawut (Pinnisetum spp.) sebagai pangan serealia alternatif. Jurnal Bionatura. 5 (1): 11-20.

Onwurafor, EU., JC. Onweluzo \& AM. Ezeoke. 2014. Effect of Fermentation Methods on Chemical and Microbial Properties of Mung Bean (Vigna radiata) Flour. Nigerian Food Journal. 32(1): 89-96.

Pallauf, J. \& Rimbach G. 1996. Nutritional significance of phytic acid and phytase. Archives of Animal Nutrition. 50(4): 301319.

Pasquale, MD. The Essentials of Essential Fatty Acids. Journal of Dietary Supplements. 6 (2):143-161.

Pranoto, Y., S. Anggrahini \& Z. Efendi. 2013. Effect of natural and Lactobacillus plantarum fermentation on invitro protein and starch digestibilities of sorghum flours. Food Bioscience. 2: 46-52.

Qu, D., J. He, C. Liu, J. Zhou \& Y. Chen. 2014. Triterpene-loaded microemulsion using 
Coix lacryma-jobi seed extract as oil phase for enhanced antitumor efficacy: preparation and in vivo evaluation. International Journal of Nanomedicine. 9 (1): 109-119.

Quan, CS., SD. Fan, LH. Zhang, YJ. Wang \& Y. Ohta. 2002. Purification and properties of a phytase from Candida krusei WZ-001. Journal of Bioscience and Bioengineering 94(5): 419-425.

Rao, Q. JR. Rocca-Smith \& TP. Labuza. 2013. Storage stability of hen egg white powders in three protein/water dough model systems. Food Chemistry. 138(23): 1087-1094.

Romito, MDK. 2019. Minerals: Their Functions and Sources. Michigan Medicine. University of Michigan.

Rusli, RK. 2011. Giving grounds remaining mixture Bran and Tofu Fermentation with Monascus purpureus Performance and Eggs Quality of Layer. [Tesis]. Teknologi Industri Pakan Fakultas Peternakan Universitas Andalas. Program Pascasarjana Universitas Gadjah Mada, Yogyakarta.

Saitou, N. \& M. Nei. 1987. The neighbor-joining method: A new method for reconstructing phylogenetic trees. Molecular Biology and Evolution 4: 406-425.

Salosa, YY. 2013. Uji kadar formalin, kadar garam dan total bakteri ikan asin tenggiri asal Kabupaten Sarmi Provinsi Papua. Depik 2(1):10-15.

Sharifi-Rad, J., CF. Rodrigues, F. Sharopov, AO. Docea, AC. Karaca, M. Sharifi-Rad, DK. Karıncaoglu, G. Gülseren, E. Şenol, E. Demircan, Y. Taheri, HAR. Suleria, B. Özçelik, KN. Kasapoğlu, M. GültekinÖzgüven, C. Daşkaya-Dikmen, WC. Cho, N. Martins \& D. Calina. 2020. Diet, Lifestyle and Cardiovascular Diseases: Linking Pathophysiology to Cardioprotective Effects of Natural Bioactive Compounds. International Journal of Environmental Research and Public Health. 17(2326): 2 -31 .

Sholikhah, WF., LT. Yuswanto, A. Widianto \& M. Shofi. 2010. Pemanfaatan Jepen Sebagai Bahan Pangan Alternatif Dalam Upaya Menanggulangi Krisis Pangan
Masyarakat Bondowoso Jawa Timur. Jenis Kegiatan PKM-AI. Universitas Negeri Malang, Malang.

Steinkraus, KH. 2006. Fermentations in world food processing CRFSFS. Comprehensive Reviews in Food Science and Food Safety. 1(1): 23-32.

Sulistiani 2017. Senyawa Antibakteri yang Diproduksi oleh Lactobacillus plantarum dan Aplikasinya untuk Pengawetan Bahan Ikan. Jurnal Biologi Indonesia 13 (2): $233-240$.

Sulistiani, A. Dinoto, H. Julistiono, R. Handayani, AP. Roswiem, PN. Sari \& S. Saputra. 2020. Seleksi Bakteri Asam Laktat dari Nira Aren [(Arenga pinnata (Wurmb)] Asal Papua Sebagai Kandidat Probiotik. Jurnal Biologi Indonesia. 16 (1):1-11.

Tamura, K., D. Peterson, N. Peterson, G. Stecher, M. Nei \& S. Kumar . 2011. MEGA5: Molecular Evolutionary Genetics Analysis using Maximum Likelihood, Evolutionary Distance, and Maximum Parsimony Methods. Molecular Biology and Evolution. 28: 2731-2739.

Uvere, PO., EU. Onyekwere \& PO. Ngoddy. 2010. Production of maize-bambara groundnut complementary foods fortified prefermentation with processed foods rich in calcium, iron, zinc and provitamin A. Journal of Science of Food and Agriculture. 90(4): 566-573.

Wang, CY., SJ. Wu, YT. Shyu. 2014. Antioxidant properties of certain cereals as affected by food-grade bacteria fermentation. Journal of Bioscience and Bioengineering. 117(4): 449- 456.

Windrati, WS., HP. Bambang, N. Diniyah. 2014. Pengembangan Teknologi Pangan Berbasis Koro- Koroan sebagai Bahan Pangan Alternatif Pensubtitusi Kedelai. Executive Summary dan Abstrak Penelitian Unggulan Perguruan Tinggi. Universitas Jember.

Wizna, MH. Abbas, Y. Rizal, A. Djulardi \& H. Muis. 2012. The effect of supplementation of micro nutrient on nutrient rice bran which fermented by Bacillus amyloliquefaciens. Pakistan Journal of Nutrition 11: 439-443. 
